\title{
EFFECTIVE REMEDY FOR EXCESSIVE LENGTH OF PROCEEDINGS: A MACEDONIAN PERSPECTIVE
}

\author{
Tatjana Zoroska Kamilovska \\ t.zoroskakamilovska@pf.ukim.edu.mk
}

Summary: 1. Introduction. - 2. The Notions of an 'Effective Remedy' and an 'Effective Remedy for Excessive Length of Proceedings.' - 3. Creating an Effective Remedy for Excessive Length of Proceedings in North Macedonia. - 3.1. Some General Facts and Figures about the Macedonian Human Rights Dossier at the ECHR. - 3.2. No Effective Length-ofproceedings Remedy until 2005. - 3.3. A First Step towards Creating an Effective Remedy. - 3.4. Other Steps forward. 4. Follow up: some Aspects of Practical Implementation of the Length-of-proceedings Remedy in North Macedonia. 5. Concluding Remarks.

To cite this article: $T$ Zoroska Kamilovska 'Effective Remedy for Excessive Length of Proceedings: A Macedonian Perspective' 2021 1(9) Access to Justice in Eastern Europe 61-78. D0I: 10.33327/AJEE-18-4.1-a000046

To link to this article: https://doi.org/10.33327/AJEE-18-4.1-a000046

Submitted on 01 Jan 2020 / Revised 24 Jan 2021 / Approved 22 Feb 2021 / Published online: 01 Mar 2021 View data Submit your article to Access to Justice in Eastern Europe http://ajee-journal.com/submissions

\section{ACKNOWLEDGEMENTS}

The author would like to express their gratitude to the reviewers for their help and for the English editor, Sarah White.

\section{CONFLICT OF INTEREST}

The author has declared that no conflict of interest or competing interests exist.

\section{CONTRIBUTOR}

The author contributed solely to the intellectual discussion underlying this paper, case-law exploration, writing and editing, and accepts responsibility for the content and interpretation.

Dr. Tatjana Zoroska Kamilovska is a professor of Civil Procedure at the Faculty of Law 'lustinianus Primus', Ss. Cyril and Methodius University in Skopje, North Macedonia. 


\title{
EFFECTIVE REMEDY FOR EXCESSIVE LENGTH OF PROCEEDINGS: A MACEDONIAN PERSPECTIVE
}

\author{
Zoroska Kamilovska Tatjana \\ Professor at the Law Faculty, \\ Ss. Cyril and Methodius University, \\ Skopje, North Macedonia
}

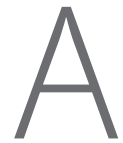

bstract In the spirit of Latin maxim Ubi jus, ibi remedium, it is claimed that the right to an effective remedy permeates the entire European Convention human rights system, giving it a real and effective dimension. An argument is also made for a right to a trial within a reasonable time, meaning that an excessive length of proceedings can be remedied as well. As the principle of subsidiarity lies at the heart of the jurisdiction of the European Court of Human Rights, the establishment of an effective remedy before the national bodies/authorities is required. In the light of these general considerations, while celebrating the $70^{\text {th }}$ anniversary of the European Convention of Human Rights, the underlying idea of this article is to highlight the fundamental standards of assessing the effectiveness of the remedies with regard to the length of proceedings established in European Court of Human Rights case-law. The focus is placed on the development, current status and functioning of the remedy for excessive length of proceedings in North Macedonia as a Member State of the Council of Europe. The article attempts to answer the question of whether the legal remedy for excessive length of proceedings that exists in Northern Macedonia can be considered effective within the meaning of the European Convention of Human Rights and the European Court of Human Rights case-law.

Keywords: a right to a trial within a reasonable time; excessive length of proceedings; undue delays; an effective remedy; an effective length-of-proceedings remedy; ECtHR case-law; jurisprudence of the Supreme Court of North Macedonia.

\section{INTRODUCTION}

The development of procedural law over the last few decades has been profoundly marked by the penetration of the idea of fairness and, consequently, by the affirmation of the concept of a fair trial as an aggregate notion of the basic principles of administration of justice. The concept is articulated and realised through an essential minimum of procedural guarantees/values as permanent and invariable elements of the civilised system of the proper administration of justice. ${ }^{1}$ Among them, the reasonable time requirement is one of the most frequently invoked

1 In this regard, recall the words of Robert S Summers that every legal process can be seen not only from the perspective of its result but also from viewpoint of the process Articleitself. Thus, he used the phrase 'process values' 'to refer to standards of value by which we may judge a legal process to be good as a process, apart from any "good result efficacy" it may have'. See Robert S Summers, 'Evaluating and Improving Legal Process - A Plea for "Process Values” (1974) 60 (1) Cornell Law Review 1 and 3.

In a similar vein, in Golder $v$ the United Kingdom, dating back to 1975, it has been outlined that 'Article 6 ... enunciates rights which are distinct but stem from the same basic idea and which, taken together, make up a single right': thus, the right to a court is coupled with a string of 'guarantees laid down ... as regards both the organisation and composition of the court, and the conduct of the proceedings. In sum, the whole makes up the right to a fair hearing. See Golder v the United Kingdom App No 4451/70 (ECtHR, 21 February 1975) para.para. 28 and $36<\mathrm{http} / / /$ hudoc.echr.coe.int/eng?i=001-57496> accessed 11 January 2020. 
components of a fair trial. Its conceptual substratum is the demand that the subjects whose rights are protected in court proceedings should not be exposed to long-lasting uncertainty for the final outcome of the proceedings and that they should have their legal matters resolved within a foreseeable and relatively predictable time period. Excessive delays in the administration of justice constitute an important danger, particularly as regards the rule of law. ${ }^{2}$ Hence, the reasonable time guarantee serves to ensure public trust in the administration of justice and to protect parties to proceedings against excessive procedural delays.

Under the influence of numerous international documents, especially the Convention for the Protection of Human Rights and Fundamental Freedoms - commonly referred to as the ECHR, ${ }^{3}$ nowadays, the standard of 'a trial within a reasonable time' is a procedural ideal that shapes the procedural and, even more so, the judicial system in each European State. Art. 6(1) of the ECHR reads as follows: 'In the determination of his civil rights and obligations or of any criminal charge against him, everyone is entitled to a fair and public hearing within a reasonable time by an independent and impartial tribunal established by law [...]'. Hence, States should organise their respective judicial systems so as to enable their courts to guarantee the right to obtain a final decision within a reasonable time. As a regulative rule with a high level of abstraction, the standard of 'a trial within a reasonable time' is a principle that should be followed by the legislator in the creation of procedural rules. It is also a direction that should be succeeded by the courts in the application of such rules. From a perspective of the subjects of rights, this standard aggregates their legitimate right to have the proceedings for the protection of the rights completed in a time period that excludes undue delays. It is generally accepted that the notion of reasonableness must reflect the necessary balance between prompt and fair proceedings. The standard of 'a trial within a reasonable time' affirms the celerity of the proceedings to the extent that it excludes undue delays. ${ }^{4}$

Contrary to the set standard, the length of proceedings is a very complex problem that many European States experience with different degrees of gravity: for some of them, it is a generalised problem, a 'systemic' one, whereas, for others, it must rather be seen as an occasional dysfunction of an otherwise effective system of administration of justice. ${ }^{5}$

No doubt, a first guarantee that a right to a trial within a reasonable time will be granted is the proper application of procedural rules by the courts in terms of preparing a case and the speedy conduct of a trial. It also includes due diligence by the parties in the proceedings. These are important preconditions for the timely realisation of the right that is being decided on in the proceedings. But, what happens when the application of the procedural rules and due diligence does not provide the expected results? The reasonable speed in taking procedural steps has to be provided by other means, ie, remedies designed to expedite the proceedings in order to prevent them from becoming excessively lengthy or to order adequate reparations. Hence, it follows that the right to a trial within a reasonable time is an autonomous right that per se deserves protection, irrespective of the protection of the right on which the court decides in the proceedings. The right to a trial within a reasonable time itself should be reinforced by a right to an effective remedy in cases of its violations.

2 Interim Resolution DH (97)336 of 11 July 1997 concerning the length of civil proceedings in Italy: supplementary measures of a general character - Group of cases CETERONI.

3 Convention for the Protection of Human Rights and Fundamental Freedoms (signed 4 November 1950, entered into force 3 September 1953).

$4 \quad$ See CH van Rhee (ed), The Law's Delay. Essays on Undue Delay in Civil Litigation (Intersentia 2004).

5 European Commission for Democracy through Law (Venice Commission), Report on the Effectiveness of National Remedies in Respect of Excessive Length of Proceedings CDL-AD (2006)036rev (Venice, 15-16 December 2006) <https://www.venice.coe.int/webforms/documents/default.aspx?pdffile=CDL$\mathrm{AD}(2006) 036 \mathrm{rev}-\mathrm{e}>$ accessed 11 January 2021. 
The European human rights system has not only influenced the national legal systems to proclaim the fundamental right to a trial within a reasonable time (providing at the same time procedure and sanctions in the cases of violations on a supranational level), but has also provided an impetus in the establishment of effective domestic legal procedures for the protection of that right, and given guidelines for their further improvement. This article is not intended to provide a detailed description of the development of the effective length-of-proceedings remedies in Member States following the relevant ECtHR case-law, but rather to recall some leading cases that have paramount importance in establishing such remedies. In light of this, the focus is on the development, current status, and functioning of the remedy for excessive length of proceedings in North Macedonia as a Member State of the Council of Europe.

\section{THE NOTIONS OF AN ‘EFFECTIVE REMEDY' AND AN ‘EFFECTIVE REMEDY FOR EXCESSIVE LENGTH OF PROCEEDINGS'}

The establishment of an effective remedy before the national bodies/authorities for the protection of any right guaranteed by the ECHR is an obligation for the Contracting States under Art. 13 of the ECHR. It states that:

Everyone whose rights and freedoms as set forth in this Convention are violated shall have an effective remedy before a national authority notwithstanding that the violation has been committed by persons acting in an official capacity.

Even though the effectiveness of human rights largely depends on the effectiveness of the remedies provided to redress their violation, almost three decades from the beginning of the implementation of the ECHR, the controlling bodies in Strasbourg had a rather indifferent position toward the application of this provision. They avoided analysing and interpreting it, and the provision became one of the most unclear provisions of the ECHR.

At the beginning of the 1980s, in the judgment rendered in the case of Silver and others $v$ United Kingdom, ${ }^{6}$ the ECtHR established several principles that were considered a necessary critical mass of requirements for the applicability of Art. 13 of the ECHR. The ECtHR held that in cases 'where an individual has an arguable claim to be the victim of a violation of the rights set forth in the Convention, he should have a remedy before a national authority in order both to have his claim decided and, if appropriate, to obtain redress'. According to the Court, the term 'national authority', 'may not necessarily be a judicial authority but, if it is not, its powers and the guarantees which it affords are relevant in determining whether the remedy before it is effective'. The Court further considered that 'although no single remedy may itself entirely satisfy the requirements of Art. 13, the aggregate of remedies provided for under domestic law may do so. Finally, the Court noted that 'neither Art. 13 nor the Convention in general lays down for the Contracting States any given manner for ensuring within their internal law the effective implementation of any of the provisions of the Convention - for example, by incorporating the Convention into domestic law.'

In regard to the protection of the right to a trial within a reasonable time, the dominant position in early case-law of the Convention bodies was that the question of an effective remedy for the protection of this right is absorbed in Art. 6(1), which requires a trial within a reasonable time and even provides for stricter guarantees than Art.13 of the ECHR. As a

$6 \quad$ Silver and others $v$ United Kingdom App Nos 5947/72, 6205/73, 7052/75, 7061/75, 7107/75, 7113/75 and 7136/75 (ECtHR, 25 March 1983) <http://hudoc.echr.coe.int/eng?i=001-57577> accessed 11 January 2021. ibid para 113 . 
result, Art. 6(1) was deemed to constitute a lex specialis in relation to Art. 13, so the latter Article was not considered even when Art. 6(1) was found to be violated. ${ }^{8}$

However, this approach was not immune to criticism. In their separate dissenting opinions in the case of Airey $v$ Ireland, Judges O’Donoghue, Thór Vilhjálmsson, and Evrigenis state that in their opinion, the Court should have examined the complaint under Art. 13 of the ECHR as well, since there was not any overlapping or absorption as regards the provisions of Art. 6(1) and Art. 13. ${ }^{9}$ Several years later, this criticism was expressed again by Judges Pinheiro Farinha and De Meyer in their joint separate opinion in the $W v$ the United Kingdom. ${ }^{10}$ They noted:

\begin{abstract}
We are not quite sure that such examination was made superfluous by the finding of a violation, in the case of the applicant, of the entitlement to a hearing by a tribunal within the meaning of Article 6 para. 1. Are the "less strict" requirements of Art.13 truly "absorbed" by those of Art. $6 \$ 1$ ? Do these provisions really "overlap"? It appears to us that the relationship between the right to be heard by a tribunal, within the meaning of Art. $6 \$ 1$, and the right to an effective remedy before a national authority, within the meaning of Art. 13, should be considered more thoroughly.
\end{abstract}

The judgment rendered in the case of Kudla $v$ Poland $^{11}$ is a turning point in the practice of the European control mechanism, as, for the first time, the ECtHR considered that it was necessary to examine an application under Art. 13 when a violation of Art. 6(1) had been found. Therefore, the correct interpretation of Art. 13 should be that it guarantees an effective remedy for an alleged breach of the right to have a court case determined within a reasonable time. The ECtHR held that

The question of whether the applicant in a given case did benefit from trial within a reasonable time in the determination of civil rights and obligations or a criminal charge is a separate legal issue from that of whether there was available to the applicant under domestic law an effective remedy to ventilate a complaint on that ground. ${ }^{12}$

Furthermore, the ECtHR observed that the subsidiary character of the Convention machinery is articulated in Art. 13 and Art. 35(1), and the former gives direct expression to the States' obligation to protect human rights primarily within their own legal systems. With this in mind, the Court has decisively stated that

If Art. 13 is [...] to be interpreted as having no application to the right to a hearing within a reasonable time as safeguarded by Art. $6 \$ 1$, individuals will systematically be forced to refer to the Court in Strasbourg complaints that would otherwise [...] have to be addressed in the first place within the national legal system. In the long term the effective functioning, on both the national and international level, of the scheme of human rights protection set up by the Convention is liable to be weakened. ${ }^{13}$

Although after the Kudla case, the ECtHR started to insist on the need to establish effective national remedies applying Art. 13 of the ECHR to all length of proceedings cases, the

8 David John Harris, Michael O’Boyle, Ed Bates, Carla Buckley, Law of the European Convention on Human Rights (Oxford University Press, 2014) 777. See also Airey v Ireland App No 6289/73 (ECtHR, 9 October 1979) para 35 <http://hudoc.echr.coe.int/eng?i=001-57420 accessed 11 January 2021; Kamasinski v Austria App No 9783/82 (ECtHR, 19 December 1989) para $110<$ http://hudoc.echr.coe. int/eng?i=001-57614> accessed 11 January 2021.

9 See Airey $v$ Ireland (n 8).

10 See $W v$ the United Kingdom App No 9749/82 (ECtHR, 8 July 1987) <http://hudoc.echr.coe.int/ eng?i=001-57600 > accessed 11 January 2021.

11 Kudla v Poland App No 30210/96 (ECtHR, 26 October 2000) <http://hudoc.echr.coe.int/ eng? $\mathrm{i}=001-58920>$ accessed 11 January 2021.

12 ibid para 147.

13 ibid para 155. 
increasing number of applications to the ECtHR for excessive length of proceedings cast doubts as to the effectiveness of the existing national remedies.

Following the impetus given by the ECtHR in Kudla judgment, the Committee of Ministers of the Council of Europe has adopted the Recommendation (2004)6 on the improvement of domestic remedies, ${ }^{14}$ which has emphasised the subsidiary character of the control mechanism in Strasbourg, recommending the member States to establish effective legal remedies for the protection of the rights guaranteed by the ECHR in their national legal system, with particular emphasis to the right of a trial within a reasonable time. ${ }^{15}$ According to this Recommendation, the member States should provide domestic legal remedies that must be 'effective' in law as well as in practice, ${ }^{16}$ and more importantly, these remedies must deal with the substance of any 'arguable claim under the Convention and to grant appropriate redress for the violation suffered. Each Member State has a discretionary power to choose the particular legal remedies: 'It is for Member States to decide which system is most suited to ensuring the necessary protection of Convention rights, taking into consideration their constitutional traditions and particular circumstances'. ${ }^{17}$ Additionally, in the ECtHR's view, the protection afforded by Art. 13 does not go so far as to require any particular form of remedy since Member States are afforded a margin of discretion in conforming to their obligations under this provision. However, the nature of the right at stake has implications for the type of remedy the States is required to provide under Art. 13. ${ }^{18}$

In this latter context, the existence of an effective remedy for the protection of a right of a trial within a reasonable time primarily encompasses its effectiveness in the course of the proceedings, whose length is brought into question. It means that the remedy is effective if it prevents the alleged violation or its continuation (mechanism of preventing delays or accelerating proceedings). In Apicella $v$ Italy, the ECtHR clearly stated that

The best solution in absolute terms is indisputably, as in many spheres, prevention. As the Court has stated on many occasions, Art. 6 para 1 imposes on the Contracting States the duty to organise their judicial systems in such a way that their courts can meet each of its requirements, including the obligation to hear cases within a reasonable time $[\ldots]$ Where the judicial system is deficient in this respect, a remedy designed to expedite the proceedings in order to prevent them from becoming excessively lengthy is the most effective solution. ${ }^{19}$

However, the effectiveness of the remedy is not disputed even in cases when there are procedures providing redress for unreasonable delays in proceedings, whether ongoing or concluded (mechanism of compensation). Therefore, Art. 13 offers an alternative: a remedy is 'effective' if it can be used either to expedite a decision by the courts dealing with the

14 Recommendation Rec (2004)6 of the Committee of Ministers to member states on the improvement of domestic remedies (adopted 12 May 2004).

15 The purpose of this Recommendation was to provide the future unloading of the ECtHR from the enormous influx of applications for violations of the Convention rights, especially from cases referring to the same problem (repetitive/clone cases), as were the cases for undue delay of the court proceedings.

16 According to the Recommendation, "the "effectiveness" of a "remedy" within the meaning of Art. 13 does not depend on the certainty of a favourable outcome for the applicant; but it implies a certain minimum requirement of speediness'.

17 For the different legal remedies in different Member States see CH van Rhee (n 4); Alan Uzelac, 'Legal Remedies for the Violations of the Right to a Trial Within a Reasonable Time in Croatia: in the quest for the holy grail of effectiveness' (2010), 35(180) Revista de Processo, 159-193; and particularly Report on the Effectiveness of National Remedies in Respect of Excessive Length of Proceedings (n 5).

18 Budayeva and Others $v$ Russia App Nos 15339/02, 21166/02, 20058/02, 11673/02 and 15343/02 (ECtHR, 20 March 2008) paras 190-191 <http://hudoc.echr.coe.int/eng?i=001-85436> accessed 11 January 2021.

19 See Apicella $v$ Italy App No 64890/01 (ECtHR, 29 March 2006) paras 72-80 <http://hudoc.echr.coe.int/ eng? $i=001-72935>$ accessed 11 January 2021. 
case or to provide the litigant with adequate redress for delays that have already occurred. ${ }^{20}$ Moreover, in different national legal systems, there can be more remedies for the protection of the right of a trial within a reasonable time, which individually might not be effective, but altogether have that quality. ${ }^{21}$ It is incumbent on the States authorities to prove, in each case submitted to the ECtHR, the effectiveness of the remedy relied upon in support of the objection of non-exhaustion of domestic remedies or the rebuttal of a complaint of a violation of Art. 13 of ECHR. By producing examples of domestic case-law, the States can have the Court accept the effective nature of the remedy. However, it is important to stress that the recognition of the effectiveness of the remedy is not obtained once and for all. It may subsequently be reviewed and challenged by the Court, either generally or in light of the particular circumstances of a given case. ${ }^{22}$

The domestic legal remedy for excessive length of the proceedings must be exhausted before initiating a procedure in Strasbourg. On the contrary, the application would be declared inadmissible for non-exhaustion of domestic remedies within the meaning of Art. 35 of the ECHR. ${ }^{23}$ The assessment of whether domestic remedies have been exhausted is normally carried out with reference to the date on which the application was lodged. However, this rule is subject to exceptions, which may be justified by the particular circumstances of each case. ${ }^{24}$

To conclude this issue, reference will be made to another Recommendation (2010)3 of the Committee of Ministers of the Council of Europe to Member States, accompanied by a Guide to Good Practice, ${ }^{25}$ as an exceptional source of information on the fundamental legal principles that apply to effective remedies for excessive length of proceedings and examples of good practices. They can help the Member States to anticipate problems that may lead to

20 See Kudla $v$ Poland (n 11), para 159, but also Cocchiarella $v$ Italy App No 64886/01 (ECtHR, 9 March 2006) paras 74-78 <http://hudoc.echr.coe.int/eng?i=001-72929> accessed 11 January 2021; Ištván and Ištvánová v Slovakia App No 30189 (ECtHR, 12 June 2012) <http://hudoc.echr.coe.int/ eng?i=001-111400> accessed 11 January 2021.

21 The ECtHR itself has adopted a directive approach to which remedy is considered effective within the meaning of Art. 13 of the ECHR, giving explicit indications as to the characteristics that effective domestic remedies for the length of proceedings should have. See Scordino $v$ Italy (No 1) App No 36813/97 (ECtHR, 29 March 2006) para $183<$ http://hudoc.echr.coe.int/eng?i=001-72925> accessed 11 January 2021; Sürmeli $v$ Germany App No 75529/01 (ECtHR, 8 June 2006) paras 79-117<http:// hudoc.echr.coe.int/fre?i=001-75689> accessed 11 January 2021; Abramiuc $v$ Romania App No 37411/02 (ECtHR, 24 February 2009) para $119<$ http://hudoc.echr.coe.int/eng?i=001-91440> accessed 11 January 2021; Tagayeva and Others $v$ Russia App No 26562/07 and 6 other applications (ECtHR, 13 April 2017) para.621 <http://hudoc.echr.coe.int/eng?i=001-172660> accessed 11 January 2021.

22 European Commission for the Efficiency of Justice (CEPEJ), Length of court proceedings in the member states of the Council of Europe based on the case law of the European Court of Human Rights, adopted at the CEPEJ 31st plenary meeting (Strasbourg), 3-4 December 2018, at $14<\mathrm{https} / / \mathrm{rm}$.coe. $\mathrm{int} /$ cepej-2018-26-en-rapport-calvez-regis-en-length-of-court-proceedings-e/16808ffc7b $>$ accessed 11 January 2020.

23 In numerous judgements, the Court reiterates that 'under Art. 35 para. 1 it may only deal with a matter after all domestic remedies have been exhausted. Applicants must have provided the domestic courts with the opportunity, in principle intended to be afforded to Contracting States, of preventing or putting right the violations alleged against them. That rule is based on the assumption, reflected in Article 13 of the Convention - with which it has close affinity - that there is an effective remedy available in the domestic system in respect of the alleged breach. The only remedies which Art. 35 para. 1 requires to be exhausted are those that relate to the breach alleged and are available and sufficient'. See, for example McFarlane v Ireland App No 31333/06 (ECtHR, 10 September 2010) para $107<$ http://hudoc.echr.coe. int/eng?i=001-100413> accessed 11 January 2021.

24 See Baumann v France App No 33592/96 (ECtHR, 22 May 2001) para. $47<$ http://hudoc.echr.coe.int/ eng?i=001-59470 $>$ accessed 11 January 2021.

25 Recommendation CM/Rec (2010)3 of the Committee of Ministers to member states on effective remedies for excessive length of proceedings (adopted by the Committee of Ministers on 24 February 2010) and the Guide to Good Practice accompanying this recommendation. 
the Court finding a violation and taking prompt action at a national level to prevent such problems and remedy them, should they arise. ${ }^{26}$

\section{CREATING AN EFFECTIVE REMEDY FOR EXCESSIVE LENGTH OF PROCEEDINGS IN NORTH MACEDONIA}

\subsection{Some General Facts and Figures about the Macedonian Human Rights Dossier at the $\mathrm{ECH}^{27}$}

The accession of North Macedonia to the ECHR was achieved in a relatively short period after it became the 38th Member State of the Council of Europe on 9 November 1995. It signed the Convention on 9 November 1995 and ratified it on 10 April 1997, when the ECHR entered into force in respect to North Macedonia. ${ }^{28}$ In that respect, it should be noted that pursuant to Art. 118 of the Constitution of North Macedonia, international treaties ratified in accordance with the Constitution are part of the internal legal order and cannot be changed by law. It means that they are superior to national legislation and receive an immediate application in case of conflict with national legislation. From this perspective, the ECHR enjoys a direct effect on the domestic legal system.

The ECtHR began to examine cases against North Macedonia two years after the Convention entered into force, and the first judgment was rendered in 2001. ${ }^{29}$ According to the ECtHR statistics for the 1959-2019 period, the Court delivered 165 judgements in respect to North Macedonia. Of course, the structure and issues raised by cases changed over time. In the first ten years, more than $75 \%$ of the admissible cases were on length of proceedings. ${ }^{30}$ In the following years, for reasons that will be explained below, this figure is significantly lower. Hence, all things considered, the Court's statistics show that out of 165 judgements delivered in respect to North Macedonia during that period, 65 judgments concerned the length of proceedings violation, while ten judgments concerned the right to an effective remedy. ${ }^{31}$

\subsection{No Effective Length-of-Proceedings Remedy until 2005}

The analysis of the constitutional and statutory framework of the right of a trial within a reasonable time in North Macedonia before the judicial reforms initiated by the Constitutional Amendments of 2005 leads us to the conclusion that the provisions establishing the right of a trial within a reasonable time in Macedonian legislation were lex imperfecta, meaning that there was no effective legal remedy for the violations of this fundamental procedural right.

$26 \quad$ ibid para 4.

27 For more details on this issue, see M Lazarova Trajkovska, I Trajkovski, 'The impact of the European Convention on Human Rights and the case law on the Republic of Macedonia', I Motoc, I Ziemele (eds), The Impact of the ECHR on Democratic Change in Central and Eastern Europe (Cambridge University Press, 2016) 266-288.

28 According to the agreement of 17 June 2018, which entered into force on 12 February 2019, as notified to international organisations on 14 February 2019, 'the former Yugoslav Republic of Macedonia' (FYR Macedonia) became the Republic of North Macedonia - short name, North Macedonia.

29 See Solakov v the FYR Macedonia App No 47023/99 (ECtHR, 31 October 2001) <http://hudoc.echr.coe. int/eng?i=001-59869> accessed 15 January 2021.

30 Mirjana Lazarova Trajkovska, Ilo Trajkovski (n 27).

31 See Statistics of the ECtHR, Violations by Article and by State 1959-2019<https://www.echr.coe.int/ Documents/Stats_violation_1959_2019_ENG.pdf> accessed 15 January 2021. 
Unlike some other Member States, the right to a trial within a reasonable time has never been enshrined in the Constitution of North Macedonia. However, the provision that established that right could be found in different statutes, starting from the Law on Courts of $1995 .^{32}$ Art. 7 of this Law stated that everyone has a right to a fair, impartial, honest, and reasonable trial. On the other hand, by virtue of the same law, the issue of remedying the excessive length of judicial proceedings was deemed to be problematic, although, within the judicial administration, there were certain mechanisms for accelerating the proceedings. In order to accelerate the judicial proceedings, the parties had the possibility to address, ie, to file a complaint to the President of the competent court or to the Ministry of Justice under Art. 76, 77, and 81 of the Law on Courts. The issue of whether these complaints were effective remedies for the length of proceedings arose before the ECtHR in the case of Janeva $v$ the FYR Macedonia. ${ }^{33}$ The Court held that the stated possibilities refer to the 'questions of the methods which might be used to accelerate the proceedings', but do not address the 'question which affects the problem of exhaustion of all legal remedies in the proceedings'. When analysing the legislation in force in North Macedonia, the Court reached a conclusion that in regard to the length of proceedings, the issue of the methods with which the applicants might have accelerated the proceedings is not an issue that concerns the problem of exhaustion of the domestic legal remedies. The remedies called upon by the Government of North Macedonia (requests for administrative supervision) do not represent an effective legal remedy as referred to in Art. 13 of the ECHR. ${ }^{34}$

In spite of the fact that the Janeva case was struck out of the list of cases as a result of a friendly settlement, ${ }^{35}$ the conclusion that in the Macedonian legal system, there is no effective legal remedy for excessive length of proceedings was reached by the ECtHR again in the judgement on the merits in Atanasovic and others v the FYR Macedonia. ${ }^{36}$ As stated by the Court in the judgement:

The Court notes that the remedies cited by the Government, that is a request to the President of the Kumanovo Municipal Court, the Ministry of Justice and the Republican Judicial Council to speed up the proceedings, effectively consist of submitting a complaint to a supervisory organ with the suggestion that it make use of its powers if it sees fit to do so. If such an appeal is made, the supervisory organ might or might not take up the matter with the official against whom the complaint is directed if it considers that the complaint is not manifestly ill-founded. Otherwise, it will take no action whatsoever. If action is taken, they would exclusively involve the supervisory organ and the officials concerned. The applicants would not be a party to any proceedings and would only be informed of the way in which the supervisory organ has dealt with their complaint. ${ }^{37}$

32 Law on Courts [Закон за судовите] (Official Gazette of the Republic of Macedonia Nos 36/95, 45/95 and 64/2003).

33 See Janeva v the FYR Macedonia App No 58185/00 (ECtHR, Decision as to the Admissibility, 23 October 2001).

34 ibid. In its communication to the ECtHR, the Representative of the Government of North Macedonia has categorically requested the Court to dismiss the complaint for non-exhaustion of the domestic legal remedies, arguing that the applicant has had the opportunity in accordance with the Law on Courts, in order to accelerate the proceedings, to address the President of the court, or the Ministry of Justice, or, more specifically with respect to the behavior of the judge from the Municipal Court in Štip, to file a complaint to the President of the court or the Republican Judicial Council. Pursuant to the Government's opinion, these actions would have accelerated the course of proceedings.

35 In this case, a friendly settlement was reached, and the Macedonian Government was obliged to pay 77,000 EUR to Ms Sofka Janeva, covering any pecuniary and non-pecuniary damage, as well as costs. See Janeva $v$ the FYR Macedonia App No 58185/00 (ECtHR, Judgment [Friendly Settlement] 3 October 2002) <http://hudoc.echr.coe.int/eng?i=001-60663> accessed 15 January 2021.

36 Atanasovic and others $v$ the FYR Macedonia App No 13886/02 (ECtHR, 22 December 2005) <http:// hudoc.echr.coe.int/eng?i=001-71813> accessed 15 January 2021.

37 ibid para 31. 
Therefore, the ECtHR found that the remedies referred to by the Government cannot be considered to be effective legal remedies for the protection of the right to trial within a reasonable time and consequently found a violation of Art. 13 of the ECHR. ${ }^{38}$

\subsection{A First Step towards Creating an Effective Remedy}

As a result, the introduction of an effective legal remedy for excessive length of proceedings in the domestic legal system became one of the priorities of the judicial reform started in 2005. Faced with the dilemma of which model of legal remedy should be accepted, the lawmakers chose the model of legal remedy within the regular judicial system (not taking into account the Constitutional Court), which provides for the adequate compensation of the damages caused by the delay of proceedings.

\section{Art. 36 of the new Law on Courts of $2006^{39}$ stated that:}

(1) The party who deems that the competent court has violated the right to a trial within a reasonable time, may submit to the immediately higher court a request for protection of the right to a trial within a reasonable time.

(2) The immediately higher court shall consider the request no later than six months of its submission and shall determine whether the lower court has violated the right to a trial within a reasonable time.

(3) In case the immediately higher court determines violation of the right to a trial within a reasonable time, it shall decide for a just satisfaction to be paid to the submitter of the request.

(4) The just satisfaction shall be provided from the judicial budget.

Seen from a comparative perspective, this model of legal remedy was closest to the one set in the Italian judicial system ${ }^{40}$ and thus (partly) satisfied the criteria of the ECtHR regarding the requirements of Art. 13 of the ECHR. ${ }^{41}$ Nevertheless, from the very first moment of enacting the new Law on Courts, several questions arose: Was the choice was the most rational? Was an additional enhancing of the chosen procedural model necessary, or would it have been more rational to introduce the model of constitutional complaint for the protection of the right to trial within a reasonable time?

At first glance, it was little surprising why, in profiling the length-of-proceedings remedy, the lawmakers did not choose the possibility to secure the mechanism of accelerating the proceedings through the same legal remedy, ${ }^{42}$ following, for example, the Austrian Fristsetzungsantrag. ${ }^{43}$ Scholars have pointed out that it might have been a better solution if the introduced legal remedy was strengthened in the following manner: during the course

38 The Court took the identical position in several other cases. See, for example, Kostovska $v$ the FYR Macedonia App No 44353/02 (ECtHR, 15 June 2006) <http://hudoc.echr.coe.int/eng?i=001-75831> accessed 15 January 2021; Rizova $v$ the FYR Macedonia App No 41228/02 (ECtHR, 6 July 2006) <http:// hudoc.echr.coe.int/eng?i=001-76267> accessed 15 January 2021.

39 Law on Courts [Закон за судовите] (Official Gazette of the Republic of Macedonia No 58/2006).

40 Pinto Act, No 89, 24 March 2001, which is the first special national act regarding the protection of the right to a trial within a reasonable time.

41 In Brusco v Italy App No 69789/01 (ECtHR-IX, 6 September 2001) <http://hudoc.echr.coe.int/ fre? $\mathrm{i}=001-22642>$ accessed 15 January 2021, the ECtHR has already held that the remedy before the courts of appeal introduced by the Pinto Act was accessible and that there was no reason to question its effectiveness.

42 It seems that the lawmakers counted on the previous novelty of procedural legislation directed towards acceleration of the proceedings, which is per se a sufficient guarantee that the application of the new procedural rules would secure a reasonable speed of proceedings, and therefore no additional procedural remedies are required.

43 See para 91 of Austrian Gerichtsorganisationsgesetz (GOG - Court Organization Act). 
of proceedings, if the party deems that there is an unreasonable delay in the taking of a particular procedural action (for example, holding a hearing, obtaining an expert's report, issuing another necessary order or taking an action which the concerned authority has failed to take), he/she may apply to a higher court for setting a time limit by which the lower court should take the required procedural action. ${ }^{44}$ This scholar's position was based on the ECtHR's opinion that a combined remedy that unites expediting and compensatory relief is probably the most effective one. ${ }^{45}$

The scholars had also pointed out several open questions that endangered the practical effectiveness of the legal remedy for just satisfaction in cases of violation of the reasonable time requirement. It was obvious that the law was not completely precise when determining the essential elements of this remedy. For example, it was not determined when the request for protection of the right to a trial within a reasonable time can be submitted: only during the course of proceedings or after its termination? And accordingly, in which time limit after the termination? It was also unclear what could be included in the just satisfaction: material or non-material damage, or both? Furthermore, the procedure for deciding upon these requests was not regulated, etc.

All these shortcomings, practical problems, and doubts became visible when the new legal remedy was put into effect (1 January 2007). The Supreme Court of North Macedonia (Supreme Court) came out with a report in which the lack of clarity of the 2006 Law and the effectiveness of the remedy were criticised. Two years later, in the case of Parizov $v$ the FYR Macedonia, ${ }^{46}$ the ECtHR held that the length-of-proceedings remedy that was introduced by the 2006 Law and became operational on 1 January 2007 cannot be considered as effective in practice since no court decision has been taken, even more than twelve months have elapsed after the introduction of the remedy. ${ }^{47}$ Therefore, the Court considers that it would be disproportionate to require the applicant to try that remedy. ${ }^{48}$

44 Tatjana Zoroska Kamilovska, 'The Lengths of Civil Proceedings and the Right of a Trial within a Reasonable Time’ (Skopje, 2006, doctoral dissertation) 421.

45 See Apicella $v$ Italy (n 19), paras 72-80 and also Cocchiarella $v$ Italy App No 64886/01 (ECtHR, 9 March 2006) <http://hudoc.echr.coe.int/eng?i=001-72929> accessed 15 January 2021.

46 Parizov $v$ the FYR Macedonia App No 14258/03 (ECtHR, 7 February 2008) <http://hudoc.echr.coe.int/ eng?i=001-84968 > accessed 15 January 2021.

47 See also Horvat $v$ Croatia App No 51585/99 (ECtHR, 26 July 2001) paras 37-39, where the ECtHR held that a national 'complaint about delays' must not be merely theoretical: there must exist sufficient caselaw proving that the application can actually result in the acceleration of a procedure or in adequate redress <http://hudoc.echr.coe.int/eng?i=001-59616> accessed 15 January 2021.

48 In Parizov v the FYR Macedonia (n 46, paras 43-44) 'the Court notes, first, that section 36 of the 2006 Act provides for a compensatory remedy - a request for just satisfaction - through which a party may, where appropriate, be awarded just satisfaction for any non-pecuniary and pecuniary damage sustained. A compensatory remedy is, without doubt, an appropriate means of redressing a violation that has already occurred [...]'. The Court further observes that the expression 'the court considers the application (постапува по барањето) within six months' is susceptible to various interpretations (see, mutatis mutandis, Horvat v Croatia, no. 51585/99, para 43, ECHR 2001-VIII). It remains open to speculation whether the proceedings upon such application should terminate within that time-limit. In addition, the 2006 Act defines two courts which may decide upon such remedy: the immediately higher court and the Supreme Court. It does not specify which court would be competent to decide if a case is pending before the Supreme Court, as it is in the present case [...] Even though the Court accepts that statutes cannot be absolutely precise and that the interpretation and application of such provisions depend on practice (see, mutatis mutandis, Kokkinakis $v$ Greece, judgment of 25 May 1993, Series A no 260-A, p 19, para. 40), the fact remains that no court decision has been taken although more than twelve months have elapsed after the introduction of the remedy. The absence of any domestic case-law appears to confirm that ambiguity'. See also Krsto Nikolov v the FYR Macedonia App No 13904/02 (ECtHR, 23 October 2008) paras 29-33 <http://hudoc.echr.coe.int/eng?i=001-89153> accessed 15 January 2021. 


\subsection{Other Steps Forward}

The same year, the Macedonian Government decided to make a proposal for amending the provisions regarding the length-of-proceedings remedy. The amendments to the Law on Courts were enacted in March $2008,{ }^{49}$ revising, among others, Art. 36 of this Law. The fundamental novelty was the establishment of an exclusive competence of the Supreme Court of North Macedonia for deciding upon the requests for protection of the right of a trial within a reasonable time. Several other provisions were added to Art. 36: first, it prescribes the time limit for submitting the request - in the course of the proceedings or not later than six months after the court decision becomes final; second, the content of the request for protection was set; ${ }^{50}$ third, the duration of the proceedings before the Supreme Court was limited to six months from submitting the request; fourth, when deciding upon the request, the Supreme Court has to take into consideration the rules and principles of ECHR, especially the complexity of the case, the conduct of the applicant and the conduct of the court in question; ${ }^{51}$ fifth, if the Supreme Court finds the violation of the right of a trial within a reasonable time, the Court shall set (with a decision) the time limit for the court before which the impugned proceedings are pending to decide on the right, obligation, or criminal responsibility of the claimant and award just satisfaction for the claimant in respect of the violation found; sixth, the satisfaction shall be paid from the Judicial budget within three months after the Supreme Court's decision becomes final; and seventh, several other questions of the procedure before the Supreme Court were also prescribed. ${ }^{52}$

The question of whether the revised length-of-proceedings remedy is effective was soon raised before the ECtHR. In Šurbanoska and others $v$ the FYR Macedonia, ${ }^{53}$ the Court found that it was still too early to deliver a judgment on the effects of the new legal remedy introduced by the amendments to the Law on Court in 2008. For that reason, the Court declared the application inadmissible. However, the Court found that that the applicants, who meanwhile used the length-of-proceedings remedy successfully, could no longer claim to have victim status. Analysing the whole background of this case, the Court stated that it is satisfied with the Supreme Court's decision of 20 October 2008, which provided the applicants with sufficient and appropriate redress capable of removing their victim status within the meaning of Art. 34 of the Convention. In addition to awarding just satisfaction, the Supreme Court set the three-month time-limit for the Bitola Court of Appeal to decide the applicants' claim in the substantive proceedings, with which the latter court had complied. ${ }^{54}$

49 Official Gazette of the Republic of Macedonia No 35/2008.

50 The request shall contain: information about the claimant and his or her representative; information about the case and proceedings complained of; indication of the reasons for the alleged violation of the right to a hearing within a reasonable time; any claim for just satisfaction; and the signature of the claimant (Art 36(3)).

51 It is obvious that the legislator has failed to mention the other relevant criterion for assessing the reasonableness of the length of proceedings - what was at stake for the applicant in the dispute. As we are familiar with the Supreme Court's practise, this criterion is leading under 'the conduct of the applicant'.

Namely, a new Art. 36-A was inserted in the Law on the Courts, which reads as follows:

'(1) After receiving the request from the Art. 36(1) of this law, the Supreme Court, shall immediately or within 15 day at the latest, request the first-instance court to forward the case file to it, and if necessary, request the higher court to indicate the reasons for the length of the proceedings pending before it.

(2) A three-judge panel of the Supreme Court, sitting in private, shall decide on the length-ofproceedings remedy. In exceptional cases, the Supreme Court may decide to hear the applicant and the representative of the court concerned.

(3) Within 8 days after receipt, the party concerned may can appeal against the panel's decision before the Supreme Court, which shall decide in accordance with Art. 35(1) of this law'.

53 Surbanoska and others $v$ the FYR Macedonia (App No 36665/03), Decision as to the admissibility, 31 August 2010.

$54 \quad$ ibid paras 39 and 44 
After this positive feedback from the ECtHR, the Law on Courts was amended once again in $2010 .{ }^{55}$ New provisions concerning the execution of the Supreme Court's decisions for payment of compensation were added in order to make this mechanism more effective in practice. ${ }^{56}$ With these amendments, the legislative process for introducing the effective legal remedy for violations of the reasonable time requirement seems to be encircled.

Until 2011, the ECtHR saw no reason to depart from its earlier case-law, in which it found a violation of Art. 13, taken in conjunction with Art. 6, due to lack of an effective remedy concerning length-of-proceedings cases. Finally, in the case of Adži-Spirkoska and others $v$ the FYR Macedonia, ${ }^{57}$ the Court found that a length-of-proceedings remedy introduced in 2008 could be regarded as effective ex nunc. In the Court's view

\begin{abstract}
The purpose of the 2008 Act is twofold. In the first place, the Supreme Court's order setting a time limit for a decision is designed to ensure the acceleration of pending proceedings [...] Secondly, the 2008 Act also provides for a compensatory remedy through which a party may be awarded just satisfaction for any damage sustained as a result of the inordinate length of the impugned proceedings [...] In such circumstances, and on the basis of the practice established by the Supreme Court, the ECtHR considers that the length remedy provided for by the 2008 Act is to be regarded, in principle, as effective within the meaning of Art. 35 para 1 of the Convention. Consequently, applicants should be required to avail themselves of it before submitting their length complaints to the Court.
\end{abstract}

Nevertheless, the ECtHR did not fail to conclude that in view of the drawbacks noted in the decision, in particular, the level of just satisfaction awarded by the Supreme Court, the Court's position may be subject to review in the future and the burden of proof as to the effectiveness of the remedy in practice remains on the respondent Government. Still, it is worth mentioning that based on this decision, in 2011, the Court disposed of several hundred length-of-proceedings cases against North Macedonia. ${ }^{58}$

\title{
4 FOLLOW UP: SOME ASPECTS OF PRACTICAL IMPLEMENTATION OF THE LENGTH-OF-PROCEEDINGS REMEDY IN NORTH MACEDONIA
}

Available statistical data shows that as of 1 January 2007, when the length-of-proceedings remedy before the Supreme Court was put into effect, the number of requests submitted to the Supreme Court was constantly increasing. In regard to the first period, until 2011, when the ECtHR issued the ground-breaking decision in Adži-Spirkoska and others case finding that a length-of-proceedings remedy as revised in 2008 could be regarded effective, the Supreme Court received 828 requests for the length of proceedings protection: 741 of these requests were in regard to civil proceedings, 147 in regard to criminal proceedings, and 90 to administrative proceedings. In 218 cases, the Supreme Court found that the requests were justified. ${ }^{59}$ The case flow of requests for protection of a right to a trial within a reasonable

55 Official Gazette of the Republic of Macedonia No 150/10.

56 It was a reaction to the ECtHR's view in Scordino $v$ Italy (n 21) that the Court can accept that the authorities need time in which to make payment. However, in respect of a compensatory remedy designed to redress the consequences of excessively lengthy proceedings, that period should not generally exceed six months from the date on which the decision awarding compensation becomes enforceable' (para 198).

57 Adži-Spirkoska and others v the FYR Macedonia App No 38914/05 (ECtHR, 3 November 2011) <http:// hudoc.echr.coe.int/fre?i=001-107569> accessed 15 January 2021.

58 Mirjana Lazarova Trajkovska, Ilo Trajkovski (n 27) 276.

59 Judge Nikolco Nikolovski, 'The Right to a fair trial, Application of the principles and standards determined with Article 6 of the ECHR - a right to a trial within a reasonable time period' (2011) 24 Business Law, Edition of law theory and practice, 77. 
time in the following period can best be traced through the annual reports on the work of the Supreme Court published on its website. ${ }^{60}$ The largest number of newly submitted requests was registered in 2012 - 676 requests - so that in the next five years (2013-2017), there was a relatively constant influx of 400-450 requests. In the last two reporting years, the number of submitted requests has decreased: 307 requests in 2018 and 241 requests in 2019. The figures alone do not answer whether the decrease in the number of requests is due to the reduced enthusiasm of users of the judicial system for this remedy or to the general increase in the efficiency of the judicial system and the shortening of the duration of court proceedings. It requires additional research, which goes beyond the scope of analysis in this paper.

Apart from these statistics, with regard to the substance, no serious studies or other research that could objectively evaluate the Supreme Court's case-law can be found. However, the ECtHR's jurisprudence has doubtless had a great impact on the Supreme Court's daily dealing with these cases, and there is no significant divergence between the Supreme Court's case-law and the ECtHR's jurisprudence regarding the right to a trial within a reasonable time. Since its earlier cases, the Supreme Court started to take into consideration the criteria that the ECtHR has established for assessing the reasonableness of the length of proceedings: the complexity of the case, the conduct of the applicant, and the conduct of the court/courts in question, applying them in each decision, ${ }^{61}$ and we will not make any further comments on this issue.

On this occasion, our analysis will be limited to several issues regarding the Supreme Court's case-law: first, the sphere of applicability of the length-of-proceedings remedy; second, the Court's assessment of excessive length of proceedings; third, the effectiveness of the orders to expedite proceedings; fourth, the sufficiency of the amount of just satisfaction; and fifth, the length of the proceedings before the Supreme Court.

Very soon after the amended Law on Courts was put into effect, the Supreme Court clearly indicated that the length-of-proceedings remedy applies only to the violations of the reasonable time requirement in court proceedings (civil, criminal, administrative disputes, etc.), but it is not available for violation of this standard in administrative proceedings. In this respect, an analysis of the case-law of the Supreme Court reveals that in its view

\begin{abstract}
the request for protection of the right of a trial within a reasonable time is an institute established by the Law on Courts, which provides the protection of such a right violated by the competent court, i.e., when the violation is carried out in judicial proceedings, and therefore the applicant has no right to apply for protection according to Art. 36(1) of the Law on Courts, when the proceedings is conducted before the Commission for denationalization [which is an administrative body]. ${ }^{62}$
\end{abstract}

However, the length of the administrative stages of proceedings is taken into consideration by the Supreme Court when assessing the reasonableness of the overall length in the cases when the administrative proceedings preceded the recourse for an administrative dispute to a court. ${ }^{63}$ It could be noted that on this issue, there is no divergence between the jurisprudence of the Supreme Court and the ECtHR's case-law. Furthermore, regarding the proceedings that have been initiated before the administrative bodies and later continued before the Administrative Court, the Supreme Court considers that from the perspective of the guarantees given by Art. 6 of the ECHR, in order to be taken into account, the

$60 \quad$ See Annual Reports <https://www.vsrm.mk> accessed 15 January 2021.

61 This is evident even from a cursory review of decisions made by the Supreme Court, which are published on its website $<$ https://www.vsrm.mk $>$ accessed 15 January 2021.

62 Decision of the Supreme Court PSRR No 48/2009. See also Decision of the Supreme Court PSRR No $40 / 2014$, where it is stated that 'protection of the right to a trial within a reasonable time cannot be sought within the meaning of Art. 36(1) of the Law on Courts, for a procedure that has finally ended before the administrative bodies, without initiating an administrative dispute. 
administrative procedure (for example, the procedure for issuing approval for urban and remedial measures, procedure for the privatisation of construction land, etc.) should have a direct, decisive influence in relation to the personal rights to ownership and use of that right on the property in question, as civil rights and obligations are not always created in the relations of involvement between the individual and the States (administrative bodies). ${ }^{64}$ This is also in line with the above-mentioned Recommendation (2010)3 on effective remedies for excessive length of proceedings, which recommends the governments of the Member States to 'take all necessary steps to ensure that all stages of domestic proceedings, irrespective of their domestic characterisation, in which there may be determination of civil rights and obligations or of any criminal charge, are determined within a reasonable time. ${ }^{65}$

Regarding the assessment of excessive length of proceedings, it is well known that the ECtHR has established a principle according to which 'the reasonableness of the duration of proceedings covered by Art. 6 of ECHR must be assessed in each case according to its circumstances. ${ }^{66}$ It is evident from the analysis of the Supreme Court's relevant decisions that the Court applies this principle. Yet, due to its relativity, there is no precise, fixed time period that should always be considered a reasonable or excessive one. For example, the Supreme Court considers that 'the period of 10 years and 10 months for the civil proceedings while 34 court hearings were held in violation of a right of a trial within e reasonable time.6. In the same case, the Supreme Court held that

\begin{abstract}
Although the claimants' - applicants ' behavior contributed to eleven years duration of civil proceedings, abusing his rights provided for in the Law on Civil Proceedings, and at the same time having the contribution of the respondent with his absence from hearings, it is the court's omission for not using its authority given with the Law on Civil Proceedings, and thus the Supreme Court found the violation of the right to a trial within a reasonable time.
\end{abstract}

On the other hand, the period of two years and seven months in the proceedings for disturbing possession is not considered to be an excessive one, although according to the Law on Civil Proceedings, this procedure is urgent and has to be terminated within six months after lodging the action. ${ }^{68}$

As far as the effectiveness of the orders to expedite proceedings is concerned, it seems that it is generally endangered since, in the majority of cases, when the Supreme Court set a time limit for a decision (from three to six months based on the complexity of the case and the stage of proceedings), the court in question did not comply with it. For example, according to statistical data, in only 36 out of 87 cases where the Supreme Court set a time limit for the decision did the courts in question comply with the Supreme Court orders. ${ }^{69}$

As regards the sufficiency of the amount of just satisfaction, analysis of the ECtHR's case-law shows that the criteria for the determination of the amount of just satisfaction depend considerably on the nature and extent of the violations the Court has found, the particular features of each case, and whether any of the damage was caused by the actions of the applicant. The Court also takes into account the local economic

64 Decision of the Supreme Court PSRR No 92/2013; Decision of the Supreme Court PSRR No 6/2014.

65 Recommendation CM/Rec (2010)3 (n 25) para 1.

66 A similar or identical sentence occurs in a number of ECtHR's judgments. See, for example Zimmermann and Steiner $v$ Switzerland App No 8737/79 (ECtHR, 13 July 1983) para $24<$ http://hudoc.echr.coe.int/ eng?i=001-57609> accessed 18 January 2021; Frydlender $v$ France App No 30979/96 (ECtHR, 27 June 2000) para $43<\mathrm{http} / / /$ hudoc.echr.coe.int/eng?i=001-58762> accessed 18 January 2021.

67 Decision of the Supreme Court PSRR No 106/2008.

68 Decision of the Supreme Court PSRR No 131/2009.

69 Judge Nikolco Nikolovski (n 59) 77. 
circumstances of the country concerned. It is the Court's settled case-law that where the national authorities have found a violation and their decision constitutes appropriate and sufficient redress, the party concerned can no longer claim to be a victim within the meaning of Art. 34 of the Convention. ${ }^{70}$ In the light of the aforementioned criteria, assessing whether the amount of compensation awarded under the domestic remedy was appropriate and sufficient, in Scordino $v$ Italy, ${ }^{71}$ the ECtHR has clearly stated that the Court can also perfectly well accept that a State which has introduced a number of remedies, one of which is designed to expedite proceedings and one to afford compensation, will award amounts which - while being lower than those awarded by the Court - are not unreasonable, on condition that the relevant decisions, which must be consonant with the legal tradition and the standard of living in the country concerned, are speedy, reasoned and executed very quickly. ${ }^{72}$

In that vein, it should be highlighted that in the Court's view, the amount of compensation can also depend on the availability of the domestic remedies that could accelerate the proceedings, in which case, the Court accepted that the compensation awarded at the domestic level (if a combined remedy is introduced) would be somewhat lower than the usual compensation awarded before it.

According to the Information on the Supreme Court's case-law in length-of proceedings cases submitted by the Macedonian Government in Šrbanoska and others $v$ the FYR Macedonia 'in cases where a violation of the "reasonable time" requirement was found, the Supreme Court awarded just satisfaction, the amount of which was in the range of EUR 80 (ПСРР.6p.86/08) and EUR 4.000 (the applicants' case). ${ }^{73}$ Finding that the total amount of compensation awarded in 46 cases was EUR 40,610, which is $15-20 \%$ of the overall amount that the ECtHR would have awarded in comparable cases, the Court considers that 'only in a very limited number of cases was the level of just satisfaction awarded by the Supreme Court acceptable, while in the vast majority of cases the awards were below or even far below the Court's standards. ${ }^{74}$ The latest available statistics of the Supreme Court show an increase of the maximum amount awarded to 500,000 denari (about 8,000 Euro), while the minimum amount remains unchanged (5,000 denari or 80 Euro).$^{75}$ Still, even in the most recent case before the ECtHR, Sinadinovska $v$ North Macedonia ${ }^{76}$ the Court found that the compensation awarded at the domestic level cannot be regarded as adequate in the circumstances of the case, and therefore, the applicant has not lost her status as a victim within the meaning of Art. 34 of the Convention. ${ }^{77}$ It should be noted that in assessing the

\footnotetext{
$\overline{70 \quad \text { Apicella } v \text { Italy (n 19) para } 70 .}$

71 Scordino $v$ Italy (n 21).

72 ibid para 206.

73 Šurbanoska and others $v$ the FYR Macedonia (n 53) para 24.

74 ibid para 38. Nevertheless, in this case, the Court is satisfied that the amount awarded to the applicants (EUR 4,000 jointly for a delay of over seventeen years, of which over eleven years elapsed after the ratification of the Convention by North Macedonia) is not manifestly unreasonable compared to what the Court generally awards in similar cases against the respondent State. ibid para 39.

75 Report on the Work of the Supreme Court of the Republic of North Macedonia for $2019<$ https://www. vsrm.mk> accessed 18 January 2021.

76 Sinadinovska $v$ North Macedonia App No 27881/06 (ECtHR, 16 January 2020) <https://laweuro. com/?p=10650> accessed 18 January 2021. See also Ogražden Ad and others $v$ the FYR Macedonia App Nos 35630/04, 53442/07 and 42580/09 (ECtHR, 29 May 2012) <http://hudoc.echr.coe.int/ eng?i=001-110943 $>$ accessed 18 January 2021.

77 Sinadinovska $v$ North Macedonia (n 76), para 49-50. The Court noted that for a period of six years and six months of the enforcement proceedings, just satisfaction was awarded at the domestic level in the total amount of MKD 60,000 (equivalent to approximately EUR 970). It does not correspond to what the Court would have been likely to award under Art. 41 of the Convention in respect to the same period. Furthermore, the domestic courts did not comply with the time-limit set by the Supreme Court.
} 
appropriateness of the compensation awarded, the Court took into consideration the fact that the available domestic remedy failed to accelerate the proceedings since the domestic courts did not comply with the time-limit set by the Supreme Court.

Finally, we will address the issue of the length of proceedings before the Supreme Court in regard to the length-of-proceedings remedy. The ECtHR pointed out that a remedy designed to address the length of proceedings may be considered effective only if it provides adequate redress speedily. According to the Court, particular attention should be paid to the speediness of the remedial action itself: it not being excluded that the adequate nature of the remedy can be undermined by its own excessive duration. ${ }^{78}$

As was mentioned above, according to the Law on Courts as revised in 2008, the duration of the proceedings before the Supreme Court is terminated to six months from submitting the request. The annual reports on work of the Supreme Court in the last decade show a constant exceeding of this time limit in more than $60 \%$ of the total number of this type of cases, stating as a reason the late submission of the case files by the court that acted in a specific case. The Supreme Court itself came out with a view that there is no legal tool by which the Supreme Court will impose itself on the lower courts for faster submission of the case files, especially in cases where the procedure relating to the request for protection of the right to a trial within a reasonable time is still in progress, whereas the essence is to create conditions to continue with the proceedings and not to wait for the decision on the request for protection of the right to a trial within a reasonable time. ${ }^{79}$ Obviously, a review should be conducted of the procedural rules for resolving this type of case before the Supreme Court, as well as the objectivity of the established time framework, which does not correspond to the ECtHR's case-law. Otherwise, there is an opportunity for the parties to complain about the excessive length of the proceedings before the Supreme Court.

\section{CONCLUDING REMARKS}

Art. 6(1) of the ECHR requires judicial proceedings to be conducted within a reasonable time, and therefore, Member States are obliged to make every effort to avoid its excessive length. The fulfilment of this obligation largely depends not only on the proper application of procedural rules and due diligence in the proceedings but also on the effectiveness of the remedies that are provided to redress violations of the reasonable time requirement. Hence, Members States have obligations in respect of the length of proceedings stemming not only from Art. 6(1) but also from Art. 13 of the ECHR. The guarantee of an effective legal remedy, including the length-of-proceedings remedy, implies that a States has a primary duty to protect the right to a trial within a reasonable time within its own legal system. As a consequence, the ECtHR exerts its supervisory role only after domestic remedies have been exhausted or when domestic remedies are unavailable, ineffective, or insufficient.

The analysis above shows that generally speaking, at the moment, the model of remedy that has been created and gradually improved in the Macedonian legal system is considered to be effective within the meaning of the ECHR. It combines the mechanism of accelerating proceedings and mechanism of compensation and doubtless has produced positive results and success in speeding up the proceedings. Nevertheless, some observations clearly indicate

78 See, for example, Vidas $v$ Croatia App No 40383/04 (ECtHR, 3 July 2008) para 37 <http://hudoc.echr. coe.int/eng?i=001-87356> accessed 18 January 2021.

79 Report on the Work of the Supreme Court of the Republic of North Macedonia for 2019 (n 75). 
that creating an effective length-of-proceeding remedy is not a definitive normative activity in North Macedonia. Further improvements are required, as the ECtHR's case-law consistently evolves and the Courts adjoin new elements to the very complex notion of an effective remedy, taking into account complaints regarding the law and practice of Member States, including North Macedonia. Moreover, it seems that no Member State has achieved perfection in creating an effective legal remedy regarding the length of proceedings, even though 'membership itself implies an obligation to strive constantly for self-improvement. ${ }^{80}$ Of course, all the possible improvements regarding the availability and effectiveness of the remedy must be the result of serious study, rather than a provisory and partial solution. Guidelines can be found in the documents of the relevant bodies of the Council of Europe, as well as in the ECtHR's case-law. Finally, it should not be overlooked that solving the issue of an effective length-of-proceedings remedy is not important only due to its compliance with the ECHR and respect to the European control mechanism, ie, the ECtHR and the authority of its decisions, but primarily because of the interests of Macedonian citizens in the proper and efficient administration of justice.

\section{REFERENCES}

Summers, 'Evaluating and Improving Legal Process - A Plea for "Process Values"'(1974) 60 (1) Cornell Law Review 1 and 3.

Convention for the Protection of Human Rights and Fundamental Freedoms (signed 4 November 1950, entered into force 3 September 1953).

Van Rhee CH (ed), The Law's delay. Essays on Undue Delay in Civil Litigation (Intersentia, 2004).

European Commission for Democracy through Law (VeniceCommission), Reporton the Effectiveness of National Remedies in Respect of Excessive Length of Proceedings CDL-AD(2006)036rev (Venice, 15-16 December 2006) <https://www.venice.coe.int/webforms/documents/default. aspx?pdffile=CDL-AD(2006)036rev-e $>$ accessed 11 January 2021.

David John Harris et al, Law of the European Convention on Human Rights (Oxford University Press, 2014) 77.

Recommendation Rec (2004)6 of the Committee of Ministers to member states on the improvement of domestic remedies (adopted 12 May 2004)

Uzelac A, 'Legal Remedies for the Violations of the Right to a Trial Within a Reasonable Time in Croatia: in the quest for the holy grail of effectiveness' (2010), 35(180) Revista de Processo, 159-193

Recommendation CM/Rec (2010)3 of the Committee of Ministers to member states on effective remedies for excessive length of proceedings (adopted by the Committee of Ministers on 24 February 2010) and the Guide to Good Practice accompanying this recommendation.

Lazarova Trajkovska M, Trajkovski I,'The impact of the European Convention on Human Rights and the case law on the Republic of Macedonia', Iulia Motoc, Ineta Ziemele (eds), The Impact of the ECHR on Democratic Change in Central and Eastern Europe, (Cambridge University Press, 2016) 266-288.

Zoroska Kamilovska T, 'The Lengths of Civil Proceedings and the Right of a Trial within a Reasonable Time' ['Траењето на парничната постапка и правото на судење во разумен рок'] (Skopje, 2006, doctoral dissertation) 421

Nikolco Nikolovski J,'The Right to a fair trial, Application of the principles and standards determined with Article 6 of the ECHR - a right to a trial within a reasonable time period' (2011) 24 Business Law, Edition of law theory and practice, 77

$80 \quad$ Guide to Good Practice: Recommendation CM/Rec (2010)3 of the Committee of Ministers to member states on effective remedies for excessive length of proceedings (Adopted by the Committee of Ministers on 24 February 2010), para 2. 